\title{
Targeted drugs for systemic therapy of lung cancer with brain metastases
}

\author{
Ya-Wen Sun ${ }^{2}$, Jian $X u^{3,4}$, Jun Zhou ${ }^{5}$ and Wen-Juan Liu ${ }^{1}$ \\ ${ }^{1}$ Shandong Provincial Key Laboratory of Radiation Oncology, Shandong Cancer Hospital and Institute, Shandong Cancer \\ Hospital Affiliated to Shandong University, Shandong Academy of Medical Sciences, Jinan, China \\ ${ }^{2}$ Shandong Cancer Hospital and Institute, Shandong Cancer Hospital Affiliated to Shandong University, Jinan, China \\ ${ }^{3}$ Laboratory of Cancer Biology and Genetics, Center for Cancer Research, National Cancer Institute, Bethesda, MD, USA \\ ${ }^{4}$ Institute of Medicinal Biotechnology, Chinese Academy of Medical Sciences and Peking Union Medical College, Beijing, China \\ ${ }^{5}$ University of South Carolina, Computer Science and Engineering Department, Columbia, SC, USA
}

Correspondence to: Wen-Juan Liu, email: 122liuwenjuan@163.com

Keywords: brain metastases; lung cancer; target drug; EGFR-TKI; ALK

Received: July 20, 2017 Accepted: October 28, $2017 \quad$ Published: December 22, 2017

Copyright: Sun et al. This is an open-access article distributed under the terms of the Creative Commons Attribution License 3.0 (CC BY 3.0), which permits unrestricted use, distribution, and reproduction in any medium, provided the original author and source are credited.

\section{ABSTRACT}

Brain metastases are very common in lung cancer patients. The condition of these patients is complicated and difficult to treat, and adverse reactions following treatment can affect the nervous system, which severely reduces quality of life. Lung cancers are categorized as small cell lung cancers and non-small cell lung cancers. Patients with brain metastasis of small cell lung cancers are generally treated with brain radiotherapy and systemic chemotherapy, but stage III/IV patients with brain metastasis of non-small cell lung cancers are generally not responsive to radiotherapy or chemotherapy. With the recent development of targeted drugs, tumor molecular profile detection allows the selection of appropriate targeted drugs for adjuvant pharmacological treatment of brain metastasis in lung cancer patients. In recent years, immune checkpoint inhibitors have emerged and have been approved by the Food and Drug Administration (FDA) for the treatment of certain cancers, but their efficacy in lung cancer patients with brain metastases still needs to be confirmed. This paper focuses on highlighting drugs for targeted therapy of brain metastasis in lung cancer patients and their molecular targets and mechanisms of drug resistance.

\section{INTRODUCTION}

In lung cancer patients, metastasis of tumors to the brain is fairly common. Among all sites of lung cancer metastasis, brain metastases account for 40-50\% $[1,2]$. After brain metastases (BM) are detected in lung cancer patients, the median survival rate is only 3-6 months [3]. Diagnosis of brain metastases in lung cancer patients is usually based on computed tomography (CT) [4-6]. Magnetic resonance imaging (MRI) can also be used to find brain metastases at early stages in asymptomatic lung cancer patients. Patients receiving early treatment have significant improvements in quality of life.

Metastasis to the nervous system occurs in $10 \%$ of small cell lung cancer (SCLC) patients and 20-40\% of non-small cell lung cancer (NSCLC) patients [7-9]. Most
$(80 \%)$ brain metastases occur in the cerebrum, $15 \%$ in the cerebellum, and $5 \%$ in the brain stem. The main treatment for brain metastasis in lung cancer patients is radiotherapy, which includes local brain radiotherapy and whole-brain radiation therapy (WBRT) $[6,10,11]$. However, over $35 \%$ of patients have adverse reactions to WBRT, and patients develop headaches, hemiplegia, and neurological diseases; the median overall survival (OS) is 4-11 months [7, 11-13].

Entry of cancer cells into the brain is extremely difficult, because they must pass through the blood-brain barrier (BBB) and survive in the microcirculation of the brain before growing into a tumor. Therapeutic drugs must also pass through the BBB to enter the brain of the patient [14]. The concentration of drugs in the central nervous system is an observable index that must be taken into account during drug development. Furthermore, resistance to such drugs can develop. 
Treatment of lung cancer brain metastases with chemotherapeutic drugs is limited by the BBB, and toxic adverse reactions to chemotherapy also cause patients to suffer [15]. Recently, an increasing number of targeted drug therapies have been used to treat brain metastases in lung cancer patients. Kirsten ras oncogene homolog $(K R A S)$ mutations, epidermal growth factor receptor (EGFR) mutations, and ROS proto-oncogene 1 (ROS1)/ anaplastic lymphoma kinase $(A L K)$ translocations are the four most common known genetic alterations in NSCLC. We will detail drugs designed against these molecular targets. Several small molecule targeted agents have been developed against the EGFR and ALK tyrosine kinases, which have increased hope for patients with brain metastases of lung cancer. Moreover, brain metastases in lung cancer have been shown to have relevant and sometimes divergent genetic alterations, and there has been a resurgence of interest in targeted drug delivery to the brain using standard or pulsatile dosing to achieve adequate drug concentration in the brain. Many clinical trials have demonstrated targeted drug efficacy. Using molecular targeting to treat brain metastasis has further increased the understanding of the molecular mechanisms of cancer.

\section{Systemic chemotherapy for small cell lung cancer}

SCLC accounts for $10-15 \%$ of all lung cancers and is often accompanied by brain metastasis [8]. The usual first-line therapy for brain metastasis is platinum-based chemotherapy or WBRT [16, 17]. However, patients receiving these treatments have poor prognoses, and the chemotherapy and prophylactic cranial radiotherapy available to help prevent brain metastases are limited in efficacy. Chemotherapeutic agents for the treatment of lung cancer brain metastasis have poor efficacy, which may be due to the BBB [18]. The use of large doses leads to the exacerbation of intracranial responses, causing brain damage.

With the continued development and clinical trials of chemotherapies, the current first-line clinical treatment of brain metastasis in lung cancer patients is mainly the use of platinum-based drugs combined with etoposide or vincristine (Table 1) [19]. The intracranial response rate to carboplatin treatment alone is $40 \%$, and its use is frequently accompanied by severe brain damage, whereas the response rate to carboplatin combined with irinotecan is $65 \%$, with a reduction in brain damage. In addition, the response rate to etoposide combined with cisplatin (Table 1) is $37 \%$, and the response rate to vinorelbine or gemcitabine combined with carboplatin is $45 \%[16,19]$. Topotecan (Table 1) is the only available second-line clinical drug for SCLCs, with an intracranial response rate of $33 \%$ [20].

\section{Cancer systemic chemotherapy for NSCLC}

NSCLC accounts for $85-90 \%$ of all lung cancers, and brain metastasis occurs in $20-40 \%$ of patients. Unlike SCLC, stage IV NSCLC patients are not sensitive to prophylactic cranial irradiation [21], and it does not extend their median survival. In addition, the intracranial response rate of the combined use of the chemotherapy drugs carboplatin and paclitaxel is only 20\% (Table 2) [22, 23]. However, during the second phase II trial, treatment of brain metastasis in NSCLC patients receiving cisplatin or pemetrexed (Table 2) combined with WBRT had brain response rates of $68.3 \%$ and $34.1 \%$, respectively, and the median OS was 12.6 months [24]. Temozolomide is a chemotherapy drug for treating brain tumors, which can also be used to treat NSCLC brain metastasis. In general, when it is used in combination with radiotherapy, the response rate is $20 \%$ [25-27]. The efficacy of the use of this drug alone is unknown.

Pemetrexed is an antifolate chemotherapy drug used to treat nonsquamous NSCLC. There are very few reports on its clinical use in treating brain metastasis in NSCLC. A study by Bearz et al. reported a partial response in 11 patients $(28.2 \%)$ and stable disease in 21 (53.8\%) after pemetrexed treatment in 39 patients found to have cancer cells in the central nervous system (CNS), with a clinical benefit rate of $82 \%$ for cranial metastases and an OS of 10 months [28]. Pemetrexed can cross the BBB to a limited extent. Its concentration in the cerebrospinal fluid is very low, at $0.33-1.58 \%$. Furthermore, there are very few reports of its use to treat brain metastasis, and therefore there is a lack of clinical evidence [29].

The data above show that treatment of lung cancer patients with brain metastasis with chemotherapy drugs (Tables 1 and 2) is restricted by the limited ability of the drugs to cross the $\mathrm{BBB}$, with response rates of $15-30 \%$, a high rate of neurological adverse events, and a lack of significant improvement of median survival, usually only 4-6 months.

Recent studies have found that the ability of tumors to metastasize to other tissues and organs is related to the presence of cancer stem cells or circulating tumor cells. New chemotherapy drugs for treating lung cancer are focused on killing cancer stem cells or circulating tumor cells; they prevent the metastasis of lung cancer cells, and they can cut off the migration of circulating tumor cells to the brain after lung cancer metastasis begins and serve as an adjuvant treatment together with radiotherapy. This requires first determining the molecular profile of circulating tumor cells, using it to determine the pharmacological type of the cancer, and then selecting the appropriate chemotherapy drugs for treatment. 


\begin{tabular}{|c|c|c|c|c|c|}
\hline Drug (trade name) & $\begin{array}{l}\text { Treatment } \\
\text { setting }\end{array}$ & $\begin{array}{l}\text { Status (year } \\
\text { approved) }\end{array}$ & $\begin{array}{l}\text { Brain } \\
\text { response } \\
\text { rate }(\%)^{\mathrm{a}}\end{array}$ & Side effects & Mechanisms of action \\
\hline Cyclophosphamide & Front Line & $\begin{array}{l}\text { Medical use } \\
\quad(1959)\end{array}$ & $53 \% / 82 \%{ }^{b}$ & Acute myeloid leukemia & $\begin{array}{l}\text { Crosslinks DNA at the } \\
\text { guanine N-7 position }\end{array}$ \\
\hline $\begin{array}{c}\text { Etoposide } \\
\text { (Etopophos) }\end{array}$ & Front Line & $\begin{array}{l}\text { Medical use } \\
\quad(1983)\end{array}$ & $53 \% / 82 \%$ b & $\begin{array}{l}\text { Infusion site reactions, } \\
\text { hair loss, constipation or } \\
\text { diarrhea, metallic food } \\
\text { taste, and bone marrow } \\
\text { suppression }\end{array}$ & $\begin{array}{l}\text { Forms complex with DNA } \\
\text { and topoisomerase II to } \\
\text { prevent re-ligation of the } \\
\text { DNA strands, causes } \\
\text { DNA strand breaks }\end{array}$ \\
\hline Teniposide (Vumon) & Front Line & Phase III & $22 \% / 57 \%{ }^{\mathrm{b}}$ & $\begin{array}{l}\text { Bone marrow suppression, } \\
\text { gastrointestinal toxicity, } \\
\text { hypersensitivity reactions, } \\
\text { and reversible alopecia }\end{array}$ & $\begin{array}{l}\text { Inhibitor of topoisomerase } \\
\text { II, causes DNA double- } \\
\text { strand breaks and DNA- } \\
\text { protein crosslinks }\end{array}$ \\
\hline $\begin{array}{l}\text { Doxorubicin } \\
\text { (Adriamycin) }\end{array}$ & Front Line & $\begin{array}{l}\text { Medical use } \\
\text { (1974) }\end{array}$ & $82 \%{ }^{b}$ & $\begin{array}{c}\text { Cardiomyopathy, } \\
\text { dyspigmentation, and skin } \\
\text { eruptions }\end{array}$ & $\begin{array}{l}\text { Causes double-stranded } \\
\text { DNA breaks, blocks } \\
\text { replication and reforming } \\
\text { of the double helix }\end{array}$ \\
\hline $\begin{array}{l}\text { Vincristine } \\
\text { (Oncovin) }\end{array}$ & Front Line & $\begin{array}{l}\text { Medical use } \\
\quad(1961)\end{array}$ & $53 \% / 82 \%{ }^{\mathrm{b}}$ & $\begin{array}{c}\text { Peripheral neuropathy, } \\
\text { hyponatremia, constipation, } \\
\text { and hair loss }\end{array}$ & $\begin{array}{l}\text { Binds tubulin to stop } \\
\text { the cell from separating } \\
\text { its chromosomes during } \\
\text { metaphase }\end{array}$ \\
\hline Cisplatin & Front Line & $\begin{array}{l}\text { Medical use } \\
\quad(1979)\end{array}$ & $85 \%{ }^{\mathrm{c}}$ & $\begin{array}{l}\text { Bone marrow suppression, } \\
\text { hair loss, kidney toxicity, } \\
\text { and vomiting }\end{array}$ & $\begin{array}{l}\text { Interferes with DNA } \\
\text { replication }\end{array}$ \\
\hline $\begin{array}{l}\text { Carboplatin } \\
\text { (Paraplatin) }\end{array}$ & Front Line & $\begin{array}{l}\text { Medical use } \\
\quad(1986)\end{array}$ & $40 \%$ & $\begin{array}{l}\text { Low blood cell levels, } \\
\text { nausea, and electrolyte } \\
\text { problems }\end{array}$ & $\begin{array}{l}\text { Causes intra-and inter- } \\
\text { strand DNA crosslinking }\end{array}$ \\
\hline $\begin{array}{c}\text { Irinotecan } \\
\text { (Camptosar) }\end{array}$ & Front Line & $\begin{array}{l}\text { Medical use } \\
\quad(1996)\end{array}$ & $65 \%$ & $\begin{array}{l}\text { Diarrhea, vomiting, bone } \\
\text { marrow suppression, } \\
\text { hair loss, shortness } \\
\text { of breath, fever, and } \\
\text { immunosuppression }\end{array}$ & $\begin{array}{c}\text { Activates to SN-38, an } \\
\text { inhibitor of topoisomerase } \\
\text { I, inhibits DNA replication } \\
\text { and transcription }\end{array}$ \\
\hline $\begin{array}{l}\text { Topotecan } \\
\text { (Hycamtin) }\end{array}$ & Second line & $\begin{array}{l}\text { FDA } \\
\text { approved } \\
(2007)\end{array}$ & $33 \%$ & $\begin{array}{c}\text { Myelosuppression, } \\
\text { anemia, thrombocytopenia, } \\
\text { diarrhea, nausea, vomiting, } \\
\text { stomatitis, constipation, } \\
\text { asthenia }\end{array}$ & $\begin{array}{c}\text { Causes single- } \\
\text { stranded DNA breaks, } \\
\text { topoisomerase I inhibitor }\end{array}$ \\
\hline
\end{tabular}

${ }^{a}$ Highest rate of brain response to drugs in the chemotherapy-only arm. ${ }^{\mathrm{b}}$ Brain response rate in patients administered chemotherapy plus whole-brain radiation therapy. ${ }^{\mathrm{c}}$ Brain response rate in Cisplatin followed by multidrug regimen.

\section{Molecularly targeted therapy for brain metastasis}

Use of the chemotherapy drugs discussed above is often accompanied by brain damage when used to treat brain metastasis in lung cancer patients. Radiographic findings of brain damage are also present when brain radiotherapy is used $[13,30,31]$. Repeated biopsies of brain metastases showed that the tumor tissue contains
EGFR suppressors, phosphoinositide 3-kinase (PI3K)/ AKT/mammalian target of rapamycin (mTOR), mitogen-activated protein kinase (MAPK), and cyclindependent kinase pathways, and other potential targets. Available small molecule targeted drugs fall mainly into two categories: EGFR-tyrosine kinase inhibitors (TKI) and ALK inhibitors [14, 30, 32, 33]. Treatment is selected based on determination of the molecular profile of the tumor. 


\begin{tabular}{|c|c|c|c|c|c|}
\hline Drug (trade name) & Treatment setting & $\begin{array}{l}\text { Status (year } \\
\text { approved) }\end{array}$ & $\begin{array}{c}\text { Brain } \\
\text { response } \\
\text { rate }(\%)\end{array}$ & Side effects & $\begin{array}{c}\text { Mechanisms of } \\
\text { action }\end{array}$ \\
\hline Paclitaxel (Taxol) & $\begin{array}{c}\text { Front Line/Second } \\
\text { Line }\end{array}$ & $\begin{array}{c}\text { FDA } \\
\text { approved } \\
(1993)\end{array}$ & $20 \%{ }^{\mathrm{a}}$ & $\begin{array}{l}\text { Hair loss, bone marrow } \\
\text { suppression, numbness, } \\
\text { allergic reactions, } \\
\text { muscle pains, and } \\
\text { diarrhea }\end{array}$ & $\begin{array}{c}\text { Targets tubulin to } \\
\text { suppress microtubule } \\
\text { detachment }\end{array}$ \\
\hline Pemetrexed (Alimta) & $\begin{array}{c}\text { Front Line/Second } \\
\text { Line }\end{array}$ & $\begin{array}{c}\text { FDA } \\
\text { approved } \\
(2004)\end{array}$ & $68.3 \% \mathrm{o}^{\mathrm{b}}$ & $\begin{array}{l}\text { Low blood cell counts, } \\
\text { nausea, diarrhea, oral } \\
\text { mucositis, loss of } \\
\text { appetite, skin rash, and } \\
\text { constipation }\end{array}$ & $\begin{array}{l}\text { Inhibits the formation } \\
\text { of precursor purine } \\
\text { and pyrimidine } \\
\text { nucleotides; prevents } \\
\text { DNA and RNA } \\
\text { synthesis }\end{array}$ \\
\hline
\end{tabular}

a. Brain Response Rate when using carboplatin and paclitaxel in patients with brain metastasis from non-small cell lung cancer.

b. Brain Response Rate when using cisplatin and pemetrexed with concurrent whole-brain radiation therapy in patients with brain metastasis from non-small cell lung cancer.

\section{First-generation EGFR-TKIs}

EGFR mutations are found in approximately $22 \%$ of all lung cancer metastases [33]. The two main signaling pathways downstream of EGFR are the RAS and PI3K pathways. The EGFR signaling pathway plays important roles in the proliferation, survival, migration, and metastasis of cancer cells. Thus, inhibition of the EGFR signaling pathway can inhibit the proliferation and metastasis of cancer cells [34, 35]. TKIs block the phosphorylation of tyrosine kinases through competitive binding, thereby inhibiting downstream signal transduction [36].

The first-generation EGFR-TKIs erlotinib (molecular weight (MW): $394 \mathrm{Da}$ ) and gefitinib (MW: 446 Da) have been approved by the United States Food and Drug Administration (FDA) for the treatment of metastatic NSCLC with EGFR mutations [37, 38] (Table 3). Lung cancer patients with brain metastasis who received erlotinib or gefitinib combined with radiotherapy or chemotherapy showed significantly increased intracranial response rates and significantly extended progressionfree survival (PFS) and median OS compared with those who received either drug alone $[39,40]$. The intracranial response rates after erlotinib or gefitinib treatment are $30-43 \%$, and the OS is 8 months $[10,41]$. In lung cancer patients with loss of EGFR exon 19 with brain metastasis, ${ }^{11} \mathrm{C}$ labeling as a positron emission tomography marker was used to show that erlotinib can pass through the BBB and enter the brain, facilitating observation of treatment efficacy [39]. EGFR-TKIs are used to treat lung cancers with EGFR mutations, and studies have shown that EGFRTKI treatment of patients with brain metastasis is also related to EGFR mutations [41-43]. Porta et al. evaluated 21 NSCLC patients with EGFR mutations treated with erlotinib and found that the condition of patients with brain metastasis improved without an obvious intracranial response [43]. It was recently reported that high doses of erlotinib (1500 mg/week) can control the condition of NSCLC patients with EGFR mutations and are well tolerated by patients; furthermore, no CNS metastases are observed [44, 45].

\section{Second-generation EGFR-TKIs}

Long-term treatment of lung cancer patients with EGFR mutations with first-generation EGFRTKIs results in the development of drug resistance and decreased treatment efficacy. This is related to secondary mutations in EGFR, and the T790M mutation underlies the main mechanism of resistance [46]. Therefore, secondgeneration EGFR-TKIs, including afatinib, dacomitinib [47], and neratinib [48] (Table 3), were introduced. In lung cancer patients with brain metastasis treated with afatinib, there is no significant improvement in PFS compared to first-line chemotherapy drugs. The intracranial response rate for afatinib alone can reach 35\% [49].

\section{Third-generation EGFR-TKIs}

Despite the efficacy of first- and second-generation EGFR-TKIs in the treatment of BM in lung cancer patients with EGFR mutations, the disease continues to progress after a short period of time. Some benefits have been reported, but they are variable and usually do not last, probably because of the poor capability of these drugs to penetrate the BBB. Repeated biopsies show that the EGFR T790M mutation underlies the main mechanism of resistance; this mutation is present in over $50 \%$ of patients. Third-generation EGFR-TKIs include osimertinib, 
Table 3: EGFR TKIs for brain metastasis in non-small cell lung cancer [46]

\begin{tabular}{|c|c|c|c|c|c|c|c|}
\hline Generation & $\begin{array}{l}\text { Drug } \\
\text { (trade } \\
\text { name) }\end{array}$ & $\begin{array}{c}\text { Treat- } \\
\text { ment } \\
\text { setting }\end{array}$ & Molecular targets & Status & $\begin{array}{c}\text { EGFR } \\
\text { inhibition }\end{array}$ & $\begin{array}{c}\text { Pivotal Trials for } \\
\text { BM }\end{array}$ & $\begin{array}{l}\text { Mechanisms of } \\
\text { drug resistance }\end{array}$ \\
\hline \multirow{2}{*}{$\begin{array}{l}\text { First genera- } \\
\text { tion }\end{array}$} & $\begin{array}{l}\text { Gefitinib } \\
\text { (Iressa) }\end{array}$ & $\begin{array}{l}\text { Second } \\
\text { line }\end{array}$ & $\begin{array}{l}\text { EGFR L858R, Del19, } \\
\text { P-glycoprotein }\end{array}$ & $\begin{array}{l}\text { Phase III } \\
\text { (FDA ap- } \\
\text { proved) }\end{array}$ & $\begin{array}{l}\text { Competi- } \\
\text { tive; } \\
\text { reversible }\end{array}$ & $\begin{array}{l}\text { IPASS trial, Li et al. } \\
\text { [10], Lee et al. [38] }\end{array}$ & $\begin{array}{l}\text { Second EGFR mu- } \\
\text { tation }\end{array}$ \\
\hline & $\begin{array}{l}\text { Erlotinib } \\
\text { (Tarceva) }\end{array}$ & $\begin{array}{l}\text { Second } \\
\text { line }\end{array}$ & EGFR L858R, Del19 & $\begin{array}{l}\text { Phase III } \\
\text { (FDA ap- } \\
\text { proved) }\end{array}$ & $\begin{array}{l}\text { Competi- } \\
\text { tive; } \\
\text { reversible }\end{array}$ & $\begin{array}{c}\text { BR.21, RTOG 0320, } \\
\text { Lee et al. [38], Porta } \\
\text { et al. [43] }\end{array}$ & $\begin{array}{l}\text { EGFR T790 muta- } \\
\text { tion; } \\
\text { MET amp }\end{array}$ \\
\hline \multirow{5}{*}{$\begin{array}{l}\text { second genera- } \\
\text { tion }\end{array}$} & & & wt-EGFR, EGFR L858R, & & & & \\
\hline & $\begin{array}{l}\text { Afatinib } \\
\text { (Gilotrif) }\end{array}$ & $\begin{array}{l}\text { Second } \\
\text { line }\end{array}$ & $\begin{array}{l}\text { L858R/T790M, L858R/ } \\
\text { T854A, wt-HER2, HER2 }\end{array}$ & $\begin{array}{l}\text { Phase III } \\
\text { (FDA ap- } \\
\text { proved) }\end{array}$ & $\begin{array}{l}\text { Covalent; } \\
\text { irreversible }\end{array}$ & $\begin{array}{l}\text { Hoffknecht et al. } \\
\qquad[36] \text {, } \\
\text { LUX-Lung } 7 / 8\end{array}$ & $\begin{array}{c}\text { Second EGFR muta- } \\
\text { tion (T790, L792F, } \\
\text { C797S) }\end{array}$ \\
\hline & & & amp, HER4 & & & & \\
\hline & Neratinib & & $\begin{array}{l}\text { EGFR L858R, T790M, } \\
\text { EGFR (G719X), MET, }\end{array}$ & Phase III & & $\begin{array}{l}\text { IPASS trial (little } \\
\text { report) }\end{array}$ & $\begin{array}{l}\text { Second EGFR muta- } \\
\text { tion (T790) }\end{array}$ \\
\hline & $\begin{array}{l}\text { Dacomi- } \\
\text { tinib }\end{array}$ & & $\begin{array}{l}\text { EGFR L858R, Del19, } \\
\text { T790M, wt-HER2, mutant- } \\
\text { HER2, HER2 amp., HER4 }\end{array}$ & Phase III & & $\begin{array}{l}\text { ARCHER } 1050 \text { trial } \\
\text { (little report) }\end{array}$ & $\begin{array}{l}\text { Second EGFR muta- } \\
\text { tion (T790) }\end{array}$ \\
\hline \multirow{7}{*}{$\begin{array}{l}\text { Third genera- } \\
\text { tion }\end{array}$} & $\begin{array}{l}\text { Osimer- } \\
\text { tinib (Tag- } \\
\quad \text { risso) }\end{array}$ & $\begin{array}{l}\text { Second } \\
\text { line }\end{array}$ & $\begin{array}{l}\text { EGFR L858R, Del19, } \\
\text { T790M } \\
\text { (limited activity against }\end{array}$ & $\begin{array}{l}\text { Phase III } \\
\text { (FDA ap- } \\
\text { proved) }\end{array}$ & $\begin{array}{l}\text { Covalent; } \\
\text { irreversible }\end{array}$ & $\begin{array}{l}\text { NCT02228369, } \\
\text { BLOOM trial }\end{array}$ & $\begin{array}{l}\text { Second EGFR mu- } \\
\text { tation }\end{array}$ \\
\hline & $\begin{array}{l}\text { Rocile- } \\
\text { tinib }\end{array}$ & & wt-EGFR, T790M & $\begin{array}{l}\text { Phase II/III } \\
\text { (stopped) }\end{array}$ & & BLOOM trial & $\begin{array}{l}\text { Second EGFR mu- } \\
\text { tation }\end{array}$ \\
\hline & Olmutinib & & $\begin{array}{c}\text { wt-EGFR, EGFR L858R, } \\
\text { Del19, T790M }\end{array}$ & $\begin{array}{l}\text { Approved in } \\
\text { South Korea }^{\mathrm{a}}\end{array}$ & & $\begin{array}{c}\text { HM-EMSI-101 } \\
\text { phase I/II }\end{array}$ & $\begin{array}{l}\text { Second EGFR mu- } \\
\text { tation }\end{array}$ \\
\hline & Nazartinib & & $\begin{array}{l}\text { wt-EGFR, EGFR L858R, } \\
\text { Del19, T790M }\end{array}$ & Phase I/II & & No reported & $\begin{array}{l}\text { Second EGFR mu- } \\
\text { tation }\end{array}$ \\
\hline & Avitinib & & $\begin{array}{l}\text { T790M (limited activity } \\
\text { against }\end{array}$ & Phase I & & No reported & $\begin{array}{l}\text { Second EGFR mu- } \\
\text { tation }\end{array}$ \\
\hline & & & wt-EGFR) & & & & \\
\hline & $\begin{array}{c}\text { AZD } 3759 \\
{[52]}\end{array}$ & & $\begin{array}{l}\text { EGFR L858R, Del19, } \\
\text { T790M, mutant-EGFR }\end{array}$ & Phase I/II & & NCT02228369 & $\begin{array}{l}\text { Second EGFR mu- } \\
\text { tation }\end{array}$ \\
\hline
\end{tabular}

${ }^{a}$ Due to an unexpected increase of grade 3/4 skin toxicity, the ELUXA clinical trial program was temporally stopped.

Del, deletion; amp, amplification; TKIs, tyrosine kinase inhibitors; wt, wild-type; EGFR, epidermal growth factor receptor;

$\mathrm{BM}$, brain metastases; MET, methyl ethyl ketone; HER/ ErbB, human epidermal growth factor receptor.

rociletinib, olmutinib, nazartinib, avitinib, and AZD3759 (Table 3). Osimertinib is a new EGFR-TKI targeting resistance due to the EGFR T790M mutation, and was recently approved by the FDA [50]. There have been two reports of brain metastasis in NSCLC patients with EGFR mutations treated with osimertinib, and there is a study in
AURA phase I/II [51]. The two patients had already been treated with gefitinib or erlotinib and brain radiotherapy, and their condition had progressed. After osimertinib treatment, patient condition and brain damage were both controlled [52]. In 2016, results from the ASCO trial were reported [53]. Among 21 lung adenocarcinoma patients, 
11 had already undergone brain radiotherapy. After daily oral administration of $160 \mathrm{mg}$ osimertinib, 5 patients had significant improvement in nervous system function, and the disease was significantly controlled in 9 patients.

\section{ALK inhibitors}

ALK rearrangements have been detected in approximately $3-7 \%$ of NSCLC cases [54]. The echinoderm microtubule-associated protein-like 4 (EML4)-ALK fusion protein was the first reported oncogenic kinase in lung cancer and is located on chromosome 2. This fusion protein includes an extracellular ligand region, a transmembrane helix region, and an intracellular domain that requires phosphorylation. After kinase activation of the protein, many oncogenes are activated by downstream signal transduction.

The first-generation ALK inhibitor crizotinib (Table 4) is taken orally [55]. It is a small molecule drug that inhibits ALK and c-Met tyrosine kinases by competing with ATP binding, thereby inhibiting the ALK-ROS1 fusion protein. In 2011, it was approved by the FDA for treatment of ALK-rearranged NSCLC patients. The PROFILE 1014 stage III, PROFILE 1005 stage II, and PROFILE 1029 stage III clinical trials all showed that, in lung cancer patients with brain metastasis, the disease control rate (DCR) of the crizotinib group was higher than the chemotherapy drug group; patients of the crizotinib group also had increased PFS and OS [55-57]. In 2010, patients taking crizotinib were found to have developed resistance [58]. Studies on the drug resistance mechanism have found that (1) ALK undergoes secondary mutations that block crizotinib from inhibiting the pathway, and (2) tumor cells can bypass ALK activation, activating this pathway by an alternate mechanism.

Drug resistance in patients treated with crizotinib has led to the introduction of the second-generation ALK inhibitors ceritinib and alectinib for the treatment of ALKpositive NSCLC (Table 4), but adverse CNS effects for these inhibitors are greater than for the first-generation ALK inhibitors. The pharmacological mechanism of ceritinib is similar to that of crizotinib, but its ALK inhibitory activity is 20-fold that of crizotinib [59]. In 2014, the FDA approved ceritinib for the treatment of metastatic ALK-positive NSCLC patients and crizotinibresistant patients [60]. In the ASCEND-1 phase I study of ceritinib, the brain response rate of patients not given ALK inhibitors was $42.1 \%$ and the brain DCR was $79 \%$, whereas the brain response rate of patients given crizotinib was $18.6 \%$ and the brain DCR was $65.2 \%$ [61, 62]. The ALK inhibitory activity of alectinib is 10 -fold that of crizotinib, and it can also inhibit leukocyte receptor tyrosine kinases and cyclin G-associated kinases.

In 2015, the FDA approved alectinib (Table 4) for the treatment of metastatic ALK-positive NSCLC patients and crizotinib-resistant patients [63]. In the phase I/II
AF-001JP clinical trial, the maximum tolerated dose was $300 \mathrm{mg}$, the brain DCR of alectinib-treated lung cancer patients with brain metastasis was $90 \%$, the brain response rate was $52.4 \%$, and the complete response rate was $29 \%$ [63-65]. Currently, alectinib treatment of brain metastasis in lung cancer patients has very good clinical efficacy. The phase II NP28761 clinical trial reported that intracranial DCR was $100 \%$.

At the 2016 ASCO annual meeting, brigatinib (Table 4) was reported to be developed for crizotinib-resistant ALK-positive NSCLC patients [66]. The activity of brigatinib in the treatment of brain metastasis in cancer is relatively good. Its targets are EGFR, ALK, ROS1, and EGFR T790M. A total of 222 NSCLC patients, of whom 154 had brain metastasis and 164 underwent chemotherapy, were randomly divided 1:1 into two groups: group A received $90 \mathrm{mg}$ brigatinib daily, and group B received $90 \mathrm{mg}$ for 7 days followed by $180 \mathrm{mg}$ daily. The objective response rate (ORR) of group B was $67 \%$, whereas the ORR of group A was only $42 \%$. The average PFS was 9.2 months for group A and 12.9 months for group B $[67,68]$.

The third-generation ALK inhibitors lorlatinib and entrectinib are still in clinical trials [69]. Entrectinib (X396) is used to treat ALK-positive NSCLC patients, and its targets are ALK, ROS1, NTRK1 (Neurotrophic Receptor Tyrosine Kinase 1), NTRK2, and NTRK-3. Lorlatinib has been reported to be effective in lung cancer patients with brain metastasis, with an ORR in target lesions reaching $60 \%$ in $\mathrm{ALK} / \mathrm{ROS} 1$ translocated tumors $[70,71]$.

\section{Other targetable molecular alterations}

ROS1 fusion genes were found in $1-2 \%$ of lung adenocarcinoma patients [72]. ROS1-positive lung adenocarcinoma patients have been treated with a combination of crizotinib and lorlatinib (Table 5), but the data have not yet been published [73-75]. The BRAF inhibitor dabrafenib (Table 5) and the MEK (methyl ethyl keytone) inhibitor trametinib have been used clinically to treat BRAF-positive lung adenocarcinoma patients [76-78]. Dabrafenib and vemurafenib [79, 80] have been approved by the FDA for the treatment of melanoma with nervous system metastasis. There have been clinical reports of dabrafenib being used to treat lung cancer patients with brain metastasis, but further clinical validation is needed.

\section{Angiogenesis inhibitors}

Tumor angiogenesis promotes NSCLC invasion and metastasis, and recently has been considered a target for treatment [81] (Figure 1). Vascular endothelial growth factor (VEGF) and other vascular growth factors, including fibroblast growth factor and platelet-derived growth factor, initiate the formation of new blood vessels 
Table 4: ALK inhibitors for brain metastasis in non-small cell lung cancer

\begin{tabular}{|c|c|c|c|c|c|}
\hline Generation & $\begin{array}{l}\text { Drug } \\
\text { (trade } \\
\text { name) }\end{array}$ & Molecular targets & Status & Pivotal trials for $\mathrm{BM}$ & $\begin{array}{l}\text { Mechanisms of drug } \\
\text { resistance }\end{array}$ \\
\hline First generation & $\begin{array}{l}\text { Crizotinib } \\
\text { (Xalkori) }\end{array}$ & $\begin{array}{l}\text { ALK-rearranged, c-Met } \\
\text { tyrosine kinase }\end{array}$ & $\begin{array}{l}\text { Phase III } \\
\text { (FDA } \\
\text { approved) }\end{array}$ & $\begin{array}{l}\text { PROFILE 1001, } \\
\text { PROFILE 1005, } \\
\text { PROFILE 1007, } \\
\text { PROFILE } 1014 \text { phase III }\end{array}$ & $\begin{array}{l}\text { Second ALK mutation } \\
\text { (L1196M and C1156Y) }\end{array}$ \\
\hline \multirow{2}{*}{$\begin{array}{c}\text { Second } \\
\text { generation }\end{array}$} & $\begin{array}{l}\text { Ceritinib } \\
\text { (Zykadia) }\end{array}$ & $\begin{array}{l}\text { ALK (L1196M, } \\
\text { G1269A, S1206Y, } \\
\text { F1174L, V1180L) }\end{array}$ & $\begin{array}{l}\text { phase I/ II } \\
\text { (FDA } \\
\text { approved) }\end{array}$ & ASCEND-1 phase I & $\begin{array}{l}\text { Second ALK mutation } \\
\text { (C1156Y, G1202R, } \\
\text { F1174C, L1152R, } \\
\text { 1151Tins, G1123S) }\end{array}$ \\
\hline & $\begin{array}{l}\text { Alectinib } \\
\text { (Alecensa) }\end{array}$ & $\begin{array}{l}\text { ALK (L1196M, } \\
\text { C1156Y, G1269A, } \\
\text { S1206Y, L1152R, } \\
\text { F1174L, 1151Tins) }\end{array}$ & $\begin{array}{l}\text { phase I/ II } \\
\text { (FDA } \\
\text { approved) }\end{array}$ & $\begin{array}{l}\text { AF-002JG phase I, } \\
\text { NP28761 Phase II }\end{array}$ & $\begin{array}{l}\text { Second ALK mutation } \\
\text { (G1202R, V1180L } \\
\text { I1171T, I1171S) }\end{array}$ \\
\hline \multirow{3}{*}{ Third generation } & brigatinib & $\begin{array}{l}\text { ALK (L1196M, } \\
\text { C1156Y, G1202R, } \\
\text { S1206Y, 1151Tins, } \\
\text { D1203N, F1174C) }\end{array}$ & phase I/ II & ALTA phase II & None reported \\
\hline & entrectinib & $\begin{array}{c}\text { ALK (L1196M, } \\
\text { C1156Y), ROS1, } \\
\text { NTRK1, NTRK2, } \\
\text { NTRK-3 }\end{array}$ & phase I & X-396 phase I & None reported \\
\hline & lorlatinib & $\begin{array}{c}\text { ALK (L1196M, } \\
\text { G1202R, G1269A) }\end{array}$ & phase I/ II & NCT01970865 & None reported \\
\hline
\end{tabular}

ALK, anaplastic Lymphoma Kinase; TKI, tyrosine kinase inhibitor; BM: brain metastases; c-MET, cellular-mesenchymal to epithelial transition factor; NTRK, Neurotrophic Receptor Tyrosine Kinase.

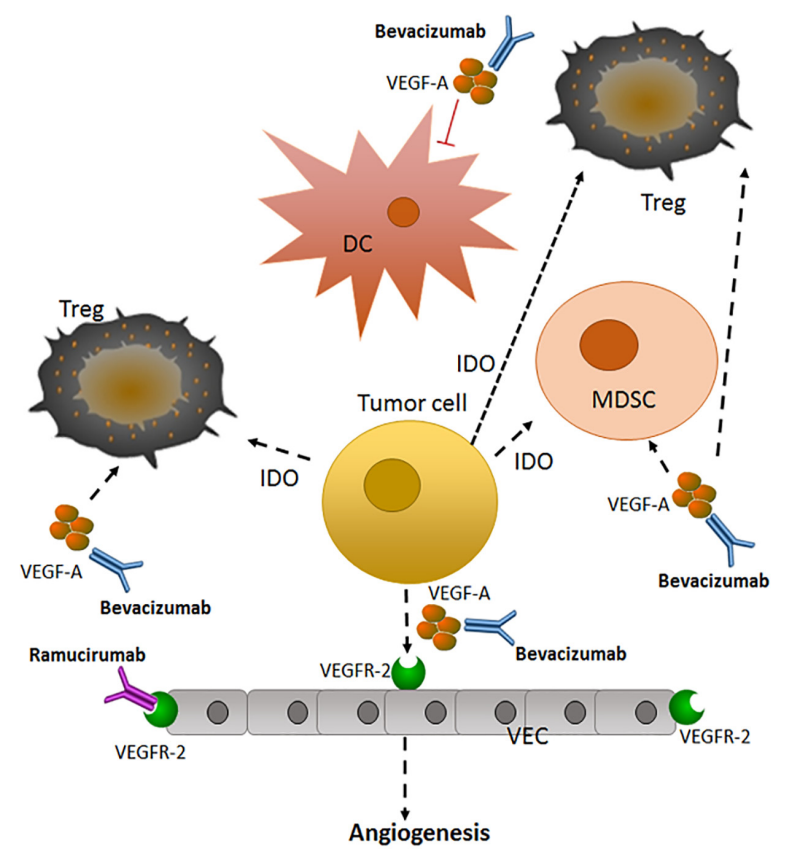

Figure 1: Anti-angiogenic therapy in advanced or metastatic NSCLC [81]. Tumor cells can secrete VEGF to promote angiogenesis, a necessary step for tumor growth and metastasis. This secreted VEGF can activate VEGFR-2 on endothelial cells, promoting the growth of new blood vessels, as well as activating signaling pathways in immune cells. Bevacizumab and ramucirumab target VEGF-A and VEGFR-2, respectively, to prevent angiogenesis. VEGF-A, vascular endothelial growth factor A; Treg, T- regulatory cell; DC: dendritic cell; VEC: vascular endothelial cell; IDO, indoleamine 2, 3 -dioxygenase; MDSC, myeloid-derived suppressor cell; VEGFR-2: vascular endothelial growth factor receptor-2. 


\begin{tabular}{|c|c|c|c|c|c|}
\hline Drug (trade names) & $\begin{array}{l}\text { Molecular } \\
\text { targets }\end{array}$ & $\begin{array}{c}\text { Targeted mutated } \\
\text { sites in NSCLC }\end{array}$ & Status & $\begin{array}{c}\text { Treatment } \\
\text { strategies for BM } \\
\text { in NSCLC }\end{array}$ & $\begin{array}{l}\text { Mechanisms of drug } \\
\text { resistance }\end{array}$ \\
\hline $\begin{array}{l}\text { Dabrafenib } \\
\text { (Tafinlar) }\end{array}$ & в-Raf & $\begin{array}{l}\text { BRAF V600E/K- } \\
\text { mutant }\end{array}$ & $\begin{array}{c}\text { FDA } \\
\text { approved }\end{array}$ & $\begin{array}{l}\text { Combination with } \\
\text { trametinib (BRAF } \\
\text { V600-positive) }\end{array}$ & $\begin{array}{c}\text { Overexpression of } \\
\text { PDGFRB, NRAS } \\
\text { mutation }\end{array}$ \\
\hline $\begin{array}{l}\text { Vemurafenib } \\
\text { (Zelboraf) }\end{array}$ & B-Raf & $\begin{array}{l}\text { BRAF V600E/K- } \\
\text { mutant }\end{array}$ & $\begin{array}{c}\text { FDA } \\
\text { approved }\end{array}$ & $\begin{array}{l}\text { Combination of } \\
\text { dabrafenib and } \\
\text { trametinib }\end{array}$ & $\begin{array}{c}\text { Overexpression of } \\
\text { PDGFRB, second NRAS } \\
\text { mutation }\end{array}$ \\
\hline $\begin{array}{l}\text { Cabozantinib } \\
\text { (Cabometyx) }\end{array}$ & $\begin{array}{c}\text { c-Met, } \\
\text { VEGFR-2, } \\
\text { AXL, RET }\end{array}$ & $\begin{array}{l}\text { RET fusion- } \\
\text { positive }\end{array}$ & $\begin{array}{c}\text { FDA } \\
\text { granted } \\
\text { orphan drug } \\
\text { status }\end{array}$ & $\begin{array}{l}\text { Combination with } \\
\text { everolimus }\end{array}$ & None reported \\
\hline $\begin{array}{l}\text { Bevacizumab } \\
\text { (Avastin) }\end{array}$ & VEGF-A & VEGF positive & $\begin{array}{c}\text { FDA } \\
\text { approved }\end{array}$ & $\begin{array}{c}\text { Combination } \\
\text { with carboplatin/ } \\
\text { paclitaxel }\end{array}$ & VEGF-D, VEGF-C \\
\hline $\begin{array}{l}\text { Ramucirumab } \\
\text { (Cyramza) }\end{array}$ & VEGFR-2 & VEGFR positive & $\begin{array}{c}\text { FDA } \\
\text { approved }\end{array}$ & $\begin{array}{c}\text { Combination } \\
\text { with carboplatin/ } \\
\text { paclitaxel }\end{array}$ & VEGFR-2 mutant \\
\hline Nivolumab (Opdivo) & PD-1 & BRAF mutant & $\begin{array}{c}\text { FDA } \\
\text { approved }\end{array}$ & $\begin{array}{l}\text { Combination with } \\
\text { ipilimumab }\end{array}$ & No reports \\
\hline $\begin{array}{c}\text { Pembrolizumab } \\
\text { (Keytruda) }\end{array}$ & PD-1 & $\begin{array}{l}\text { PD-L1 } \\
\text { overexpression, no } \\
\text { mutations in EGFR } \\
\text { or in ALK }\end{array}$ & $\begin{array}{c}\text { FDA } \\
\text { approved }\end{array}$ & Pembrolizumab & No reports \\
\hline $\begin{array}{l}\text { Atezolizumab } \\
\text { (Tecentriq) }\end{array}$ & PD-L1 & Cytotoxic T-cells & $\begin{array}{c}\text { FDA } \\
\text { approved }\end{array}$ & Atezolizumab & No reports \\
\hline $\begin{array}{l}\text { Ipilimumab } \\
\text { (Yervoy) }\end{array}$ & CTLA-4 & $\begin{array}{l}\text { Cytotoxic T } \\
\text { lymphocytes }\end{array}$ & $\begin{array}{c}\text { FDA } \\
\text { approved }\end{array}$ & $\begin{array}{l}\text { Combination with } \\
\text { carboplatin }\end{array}$ & No reports \\
\hline
\end{tabular}

NSCLC, non-small cell lung cancer; BM, brain metastases; VEGFR-2, vascular endothelial growth factor receptor 2; VEGF: vascular endothelial growth factor; PD-1, programmed cell death protein 1; PD-L1, Programmed death-ligand 1; EGFR: epidermal growth factor receptor; ALK, anaplastic lymphoma kinase; CTLA-4, cytotoxic T-lymphocyte-associated protein 4.

and change the tumor microenvironment [82, 83]. Currently, the anti-angiogenesis monoclonal antibodies bevacizumab and ramucirumab, targeting VEGF-A and its receptor (VEGFR-2), respectively, (Table 5) have been approved for the treatment of nonsquamous metastatic NSCLC $[84,85]$.

\section{Bevacizumab}

The PASSPORT trial primarily evaluated bevacizumab treatment of nonsquamous NSCLC patients, including those with brain metastasis [86-90]. Bevacizumab treatment was administered in combination with the chemotherapy drugs paclitaxel-carboplatin or erlotinib [87, 91]. Among 39 patients undergoing treatment, brain metastasis was found in 11 patients. After 6 weeks of treatment with bevacizumab and chemotherapy, the median PFS was 8.2 months and the OS was 14 months, which was not significantly different from patients without brain metastasis. Furthermore, there were no cases of contingencies or CNS hemorrhage.

The NCT02959749 is a phase III clinical trial [88]; among 147 NSCLC patients with confirmed nonsquamous lung cancer, metastasis, and EGFR T790M mutations, 74 were given osimertinib ( $80 \mathrm{mg} /$ day) and 73 were given docetaxel $\left(75 \mathrm{mg} / \mathrm{m}^{2}\right)$ and bevacizumab $(7.5$ $\mathrm{mg} / \mathrm{kg}$ ) treatment. Patients were provided treatment until their condition progressed or unexpected toxic reactions occurred. The PFS was 10.2 months in the osimertinib group and 2.95 months in the docetaxel-bevacizumab group. At the 2017 ASCO conference, many clinical trials of bevacizumab treatment of EGFR-TKI-resistant NSCLC with EGFR mutations and metastasis were reported. The combination of afatinib and bevacizumab was effective, suggesting a new regimen for the treatment of EGFRTKI-resistant NSCLC patients, but more clinical data are required. 


\section{Ramucirumab}

The REVEL trial evaluated the efficacy of ramucirumab and chemotherapy drugs used as second-line treatment in metastatic NSCLC [92-94]. The evaluation showed that ramucirumab combined with docetaxel was the most effective. In a randomized phase II trial of Japanese NSCLC patients, the PFS was 5.2 months compared with 4.2 months for placebo plus docetaxel, and the OS was 15.5 months compared with 14.7 months for placebo plus docetaxel. Based on these data, ramucirumab and docetaxel were approved by the FDA for second-line treatment of metastatic NSCLC.

\section{Immune checkpoint inhibitors}

Immune checkpoints are dysregulated in malignancies such as lung cancer. Cancer patients with brain metastasis have high rates of tumor lymphocyte invasion in the brain microenvironment [95]. However, the use of immune checkpoint inhibitors in NSCLC patients with brain metastasis is limited [96].

Nivolumab [97], pembrolizumab [98], and atezolizumab [99] with docetaxel have been approved by the FDA as second-line therapies for the treatment of NSCLC that has failed treatment with platinum-based chemotherapy drugs (Table 5). Pembrolizumab is an antiPD-1 antibody evaluated in the NCT02085070 phase II clinical trial. A dose of $10 \mathrm{mg} / \mathrm{kg}$ pembrolizumab was given to 10 NSCLC patients with brain metastasis for 2 weeks, which was effective in 9 patients, of which 4 had particularly good reactions; 1 patient experienced brain damage. A total of 18 NSCLC patients (PD-L1-positive) received continued pembrolizumab treatment. The safety of 4 weeks of continued use was evaluated, and brain MRI was used to evaluate reactions on the $8^{\text {th }}$ week. The brain response rate of 6 patients with brain metastasis was 33\%.

There are few clinical studies on the anti-PD-L1 antibody nivolumab. At the 2016 ESMO conference, it was reported that, among 372 squamous NSCLC patients, 38 patients had brain metastasis, and the DCR was $47 \%$ among all patients and $47.3 \%$ among patients with brain metastasis. Furthermore, the average PFS and OS of patients with brain metastasis were 5.5 months and 6.5 months, respectively. In a randomized phase III clinical trial, the anti-PD-L1 antibody atezolizumab combined with docetaxel was effective in controlling disease progression in NSCLC patients compared to chemotherapy alone. In addition, it extended the overall survival of patients, and no patients died during the course of administration.

The anti-CTLA-4 antibody ipilimumab $[100,101]$ increases the number of cytotoxic $\mathrm{T}$ cells, and is very effective in treating brain metastasis of melanoma (Table 5). Recently, there have been reports of treatment of brain metastasis in lung cancer using these antibodies, mostly with the combination of pembrolizumab and nivolumab.

\section{CONCLUSIONS}

Brain radiotherapy is the first treatment for brain metastasis in SCLC patients. If control cannot be achieved and the disease progresses, adjuvant treatment with platinum-based first-line chemotherapy drugs or chemotherapy alone should be used. In NSCLC patients with brain metastasis, chemotherapy cannot substitute for radiotherapy, because patients with brain metastasis are not sensitive to chemotherapy. In the current era of treatment of NSCLC with targeted drugs and immune checkpoint inhibitors, if patients meet criteria such as EGFR-mutated or ALK-positive NSCLC brain metastasis, the combination of tyrosine kinase small molecule inhibitors and radiotherapy or chemotherapy should be considered a priority. The efficacy of immunotherapy of brain metastasis in NSCLC patients has not yet been confirmed and requires further support with clinical data. Currently, the emergence of liquid biopsy and circulating tumor cell detection has permitted early diagnosis and the possibility of early treatment of brain metastases in lung cancer patients. However, the available targeted drugs for the treatment of brain metastasis in lung cancer patients benefit only some of these patients and are expensive, and further studies on the molecular mechanisms of cancer are needed to find additional targets.

\section{CONFLICTS OF INTEREST}

The authors declare that they have no conflicts of interest.

\section{FUNDING}

This study was financially supported by "Significant New Drug Development" Major Science and Technology Development Projects of China (No. 2014ZX09201042003); National Natural Science Foundation of China (NO.81502691); and Natural Science Foundation of Shandong Province (ZR2015HM040, ZR2014HP004).

\section{REFERENCES}

1. Siegel RL, Miller KD, Jemal A. Cancer Statistics, 2017. CA Cancer J Clin. 2017; 67:7-30.

2. Siegel RL, Miller KD, Jemal A. Cancer statistics, 2016. CA Cancer J Clin. 2016; 66:7-30.

3. Morgensztern D, Ng SH, Gao F, Govindan R. Trends in stage distribution for patients with non-small cell lung cancer: a National Cancer Database survey. J Thorac Oncol. 2010; 5:29-33.

4. Waqar SN, Morgensztern D. Treatment advances in small cell lung cancer (SCLC). Pharmacol Ther. 2017; 180:16-23.

5. Andrews DW, Scott CB, Sperduto PW, Flanders AE, Gaspar LE, Schell MC, Werner-Wasik M, Demas W, Ryu J, Bahary 
JP, Souhami L, Rotman M, Mehta MP, Curran WJ Jr. Whole brain radiation therapy with or without stereotactic radiosurgery boost for patients with one to three brain metastases: phase III results of the RTOG 9508 randomised trial. Lancet. 2004; 363:1665-72.

6. Borgelt B, Gelber R, Kramer S, Brady LW, Chang CH, Davis LW, Perez CA, Hendrickson FR. The palliation of brain metastases: final results of the first two studies by the Radiation Therapy Oncology Group. Int J Radiat Oncol Biol Phys. 1980; 6:1-9.

7. D'Antonio C, Passaro A, Gori B, Del Signore E, Migliorino MR, Ricciardi S, Fulvi A, de Marinis F. Bone and brain metastasis in lung cancer: recent advances in therapeutic strategies. Ther Adv Med Oncol. 2014; 6:101-14.

8. van Meerbeeck JP, Fennell DA, De Ruysscher DK. Smallcell lung cancer. Lancet. 2011; 378:1741-55.

9. Arrieta O, Saavedra-Perez D, Kuri R, Aviles-Salas A, Martinez L, Mendoza-Posada D, Castillo P, Astorga A, Guzman E, De la Garza J. Brain metastasis development and poor survival associated with carcinoembryonic antigen (CEA) level in advanced non-small cell lung cancer: a prospective analysis. BMC Cancer. 2009; 9:119.

10. Waqar SN, Morgensztern D, Govindan R. Systemic Treatment of Brain Metastases. Hematol Oncol Clin North Am. 2017; 31:157-76.

11. Zakaria N, Satar NA, Abu Halim NH, Ngalim SH, Yusoff NM, Lin J, Yahaya BH. Targeting Lung Cancer Stem Cells: Research and Clinical Impacts. Front Oncol. 2017; 7:80.

12. Berghoff AS, Preusser M. Targeted Therapies for Melanoma Brain Metastases. Curr Treat Options Neurol. 2017; 19:13.

13. Ebben JD, You M. Brain metastasis in lung cancer: building a molecular and systems-level understanding to improve outcomes. Int J Biochem Cell Biol. 2016; 78:288-96.

14. Shonka N, Venur VA, Ahluwalia MS. Targeted Treatment of Brain Metastases. Curr Neurol Neurosci Rep. 2017; 17:37.

15. Lee SH. Role of chemotherapy on brain metastasis. Prog Neurol Surg. 2012; 25:110-14.

16. Lee JS, Murphy WK, Glisson BS, Dhingra HM, Holoye PY, Hong WK. Primary chemotherapy of brain metastasis in small-cell lung cancer. J Clin Oncol. 1989; 7:916-22.

17. Kantarjian H, Farha PA, Spitzer G, Murphy WK, Valdivieso M. Systemic combination chemotherapy as primary treatment of brain metastasis from lung cancer. South Med J. 1984; 77:426-30.

18. Stewart DJ. A critique of the role of the blood-brain barrier in the chemotherapy of human brain tumors. J Neurooncol. 1994; 20:121-39.

19. Groen HJ, Smit EF, Haaxma-Reiche H, Postmus PE. Carboplatin as second line treatment for recurrent or progressive brain metastases from small cell lung cancer. Eur J Cancer. 1993; 29A:1696-99.

20. Korfel A, Oehm C, von Pawel J, Keppler U, Deppermann M, Kaubitsch S, Thiel E. Response to topotecan of symptomatic brain metastases of small-cell lung cancer also after whole-brain irradiation. a multicentre phase II study. Eur J Cancer. 2002; 38:1724-29.

21. Lester JF, MacBeth FR, Coles B. Prophylactic cranial irradiation for preventing brain metastases in patients undergoing radical treatment for non-small-cell lung cancer: a Cochrane Review. Int J Radiat Oncol Biol Phys. 2005; 63:690-94.

22. He G, Xiao X, Zou M, Zhang C, Xia S. Pemetrexed/ cisplatin as first-line chemotherapy for advanced lung cancer with brain metastases: A case report and literature review. Medicine (Baltimore). 2016; 95:e4401.

23. Lee JS, Pisters KM, Komaki R, Glisson BS, Khuri FR, Schea R, Fossella FV. Paclitaxel/carboplatin chemotherapy as primary treatment of brain metastases in non-small cell lung cancer: a preliminary report. Semin Oncol. 1997; 24:S12-52, S12-55.

24. Dinglin XX, Huang Y, Liu H, Zeng YD, Hou X, Chen LK. Pemetrexed and cisplatin combination with concurrent whole brain radiotherapy in patients with brain metastases of lung adenocarcinoma: a single-arm phase II clinical trial. J Neurooncol. 2013; 112:461-66.

25. Verger E, Gil M, Yaya R, Viñolas N, Villà S, Pujol T, Quintó L, Graus F. Temozolomide and concomitant whole brain radiotherapy in patients with brain metastases: a phase II randomized trial. Int J Radiat Oncol Biol Phys. 2005; 61:185-91.

26. Dziadziuszko R, Ardizzoni A, Postmus PE, Smit EF, Price A, Debruyne C, Legrand C, Giaccone G, and EORTC Lung Cancer Group. Temozolomide in patients with advanced non-small cell lung cancer with and without brain metastases. a phase II study of the EORTC Lung Cancer Group (08965). Eur J Cancer. 2003; 39:1271-76.

27. Antonadou D, Paraskevaidis M, Sarris G, Coliarakis N, Economou I, Karageorgis P, Throuvalas N. Phase II randomized trial of temozolomide and concurrent radiotherapy in patients with brain metastases. J Clin Oncol. 2002; 20:3644-50.

28. Bearz A, Garassino I, Tiseo M, Caffo O, Soto-Parra H, Boccalon M, Talamini R, Santoro A, Bartolotti M, Murgia V, Berretta M, Tirelli U. Activity of Pemetrexed on brain metastases from Non-Small Cell Lung Cancer. Lung Cancer. 2010; 68:264-68.

29. Kumthekar P, Grimm SA, Avram MJ, Kaklamani V, Helenowski I, Rademaker A, Cianfrocca M, Gradishar W, Patel J, Mulcahy M, McCarthy K, Raizer JJ. Pharmacokinetics and efficacy of pemetrexed in patients with brain or leptomeningeal metastases. J Neurooncol. 2013; 112:247-55.

30. Haughton ME, Chan MD, Watabe K, Bonomi M, Debinski W, Lesser GJ, Ruiz J. Treatment of brain metastases of lung cancer in the era of precision medicine. Front Biosci (Elite Ed). 2016; 8:219-32.

31. Peters S, Bexelius C, Munk V, Leighl N. The impact of brain metastasis on quality of life, resource utilization and 
survival in patients with non-small-cell lung cancer. Cancer Treat Rev. 2016; 45:139-62.

32. Sekine A, Satoh H. Paradigm shift of therapeutic management of brain metastases in EGFR-mutant nonsmall cell lung cancer in the era of targeted therapy. Med Oncol. 2017; 34:121.

33. Bartolotti M, Franceschi E, Brandes AA. EGF receptor tyrosine kinase inhibitors in the treatment of brain metastases from non-small-cell lung cancer. Expert Rev Anticancer Ther. 2012; 12:1429-35.

34. Xu J, Du Y, Liu XJ, Zhu BY, Zhang SH, Li L, Li Y, Wang XF, Shan CK, Wang RQ, Zhen YS. Recombinant EGFR/ MMP-2 bi-targeted fusion protein markedly binding to nonsmall-cell lung carcinoma and exerting potent therapeutic efficacy. Pharmacol Res. 2017; 126:66-76.

35. Xu J, Liu XJ, Li L, Zhang SH, Li Y, Gao RJ, Zhen YS. An engineered TIMP2-based and enediyne-integrated fusion protein for targeting MMP-14 shows potent antitumor efficacy. Oncotarget. 2015; 6:26322-34. https://doi. org/10.18632/oncotarget.4709

36. Hoffknecht P, Tufman A, Wehler T, Pelzer T, Wiewrodt R, Schütz M, Serke M, Stöhlmacher-Williams J, Märten A, Maria Huber R, Dickgreber NJ, and Afatinib Compassionate Use Consortium (ACUC). Efficacy of the irreversible ErbB family blocker afatinib in epidermal growth factor receptor (EGFR) tyrosine kinase inhibitor (TKI)-pretreated nonsmall-cell lung cancer patients with brain metastases or leptomeningeal disease. J Thorac Oncol. 2015; 10:156-63.

37. Shao YY, Lin CC, Yang CH. Gefitinib or erlotinib in the treatment of advanced non-small cell lung cancer. Discov Med. 2010; 9:538-45.

38. Lee SM, Lewanski CR, Counsell N, Ottensmeier C, Bates A, Patel N, Wadsworth C, Ngai Y, Hackshaw A, FaivreFinn C. Randomized trial of erlotinib plus whole-brain radiotherapy for NSCLC patients with multiple brain metastases. J Natl Cancer Inst. 2014; 106:dju151.

39. Stewart DJ, Erasmus JJ. Erlotinib accumulation in brain metastases from non-small cell lung cancer: visualization by positron emission tomography in a patient harboring a mutation in the epidermal growth factor receptor. $\mathrm{J}$ Thorac Oncol. 2011; 6:1149-51.

40. Maemondo M, Inoue A, Kobayashi K, Sugawara S, Oizumi $\mathrm{S}$, Isobe $\mathrm{H}$, Gemma A, Harada M, Yoshizawa H, Kinoshita I, Fujita Y, Okinaga S, Hirano H, et al, and North-East Japan Study Group. Gefitinib or chemotherapy for non-small-cell lung cancer with mutated EGFR. N Engl J Med. 2010; 362:2380-88.

41. How J, Mann J, Laczniak AN, Baggstrom MQ. Pulsatile Erlotinib in EGFR-Positive Non-Small-Cell Lung Cancer Patients With Leptomeningeal and Brain Metastases: review of the Literature. Clin Lung Cancer. 2017; 18:354-63.

42. Rosell R, Carcereny E, Gervais R, Vergnenegre A, Massuti B, Felip E, Palmero R, Garcia-Gomez R, Pallares C, Sanchez JM, Porta R, Cobo M, Garrido P, et al, and Spanish Lung Cancer Group in collaboration with Groupe
Français de Pneumo-Cancérologie and Associazione Italiana Oncologia Toracica. Erlotinib versus standard chemotherapy as first-line treatment for European patients with advanced EGFR mutation-positive non-small-cell lung cancer (EURTAC): a multicentre, open-label, randomised phase 3 trial. Lancet Oncol. 2012; 13:239-46.

43. Porta R, Sánchez-Torres JM, Paz-Ares L, Massutí B, Reguart N, Mayo C, Lianes P, Queralt C, Guillem V, Salinas $\mathrm{P}$, Catot S, Isla D, Pradas A, et al. Brain metastases from lung cancer responding to erlotinib: the importance of EGFR mutation. Eur Respir J. 2011; 37:624-31.

44. Schöttle J, Chatterjee S, Volz C, Siobal M, Florin A, Rokitta D, Hinze Y, Dietlein F, Plenker D, König K, Albus K, Heuckmann JM, Rauh D, et al. Intermittent high-dose treatment with erlotinib enhances therapeutic efficacy in EGFR-mutant lung cancer. Oncotarget. 2015; 6:38458-68. https://doi.org/10.18632/oncotarget.6276

45. Kuiper JL, Heideman DA, Thunnissen E, van Wijk AW, Postmus PE, Smit EF. High-dose, weekly erlotinib is not an effective treatment in EGFR-mutated non-small cell lung cancer-patients with acquired extracranial progressive disease on standard dose erlotinib. Eur J Cancer. 2014; 50:1399-401.

46. Sullivan I, Planchard D. Next-Generation EGFR Tyrosine Kinase Inhibitors for Treating EGFR-Mutant Lung Cancer beyond First Line. Front Med (Lausanne). 2017; 3:76.

47. Zugazagoitia J, Díaz A, Jimenez E, Nuñez JA, Iglesias L, Ponce-Aix S, Paz-Ares L. Second-line Treatment of NonSmall Cell Lung Cancer: Focus on the Clinical Development of Dacomitinib. Front Med (Lausanne). 2017; 4:36.

48. Sequist LV, Besse B, Lynch TJ, Miller VA, Wong KK, Gitlitz B, Eaton K, Zacharchuk C, Freyman A, Powell C, Ananthakrishnan R, Quinn S, Soria JC. Neratinib, an irreversible pan-ErbB receptor tyrosine kinase inhibitor: results of a phase II trial in patients with advanced nonsmall-cell lung cancer. J Clin Oncol. 2010; 28:3076-83.

49. Gilbert JA. Afatinib monotherapy in EGFR-mutant lung adenocarcinoma. Lancet Oncol. 2013; 14:e345.

50. Planchard D, Brown KH, Kim DW, Kim SW, Ohe Y, Felip E, Leese P, Cantarini M, Vishwanathan K, Jänne PA, Ranson M, Dickinson PA. Osimertinib Western and Asian clinical pharmacokinetics in patients and healthy volunteers: implications for formulation, dose, and dosing frequency in pivotal clinical studies. Cancer Chemother Pharmacol. 2016; 77:767-76.

51. Jänne PA, Yang JC, Kim DW, Planchard D, Ohe Y, Ramalingam SS, Ahn MJ, Kim SW, Su WC, Horn L, Haggstrom D, Felip E, Kim JH, et al. AZD9291 in EGFR inhibitor-resistant non-small-cell lung cancer. N Engl J Med. 2015; 372:1689-99.

52. Yang Z, Guo Q, Wang Y, Chen K, Zhang L, Cheng Z, Xu Y, Yin X, Bai Y, Rabbie S, Kim DW, Ahn MJ, Yang JC, Zhang X. AZD3759, a BBB-penetrating EGFR inhibitor for the treatment of EGFR mutant NSCLC with CNS metastases. Sci Transl Med. 2016; 8:368ra172. 
53. Sullivan I, Planchard D. Osimertinib in the treatment of patients with epidermal growth factor receptor T790M mutation-positive metastatic non-small cell lung cancer: clinical trial evidence and experience. Ther Adv Respir Dis. 2016; 10:549-65.

54. Drizou M, Kotteas EA, Syrigos N. Treating patients with ALK-rearranged non-small-cell lung cancer: mechanisms of resistance and strategies to overcome it. Clin Transl Oncol. 2017; 19:658-66.

55. Costa DB, Shaw AT, Ou SH, Solomon BJ, Riely GJ, Ahn MJ, Zhou C, Shreeve SM, Selaru P, Polli A, Schnell P, Wilner KD, Wiltshire R, et al. Clinical Experience With Crizotinib in Patients With Advanced ALK-Rearranged Non-Small-Cell Lung Cancer and Brain Metastases. J Clin Oncol. 2015; 33:1881-88.

56. El Gantery MM, Abd El Baky HM, El Hossieny HA, Mahmoud M, Youssef O. Management of brain metastases with stereotactic radiosurgery alone versus whole brain irradiation alone versus both. Radiat Oncol. 2014; 9:116.

57. Solomon BJ, Mok T, Kim DW, Wu YL, Nakagawa K, Mekhail T, Felip E, Cappuzzo F, Paolini J, Usari T, Iyer $\mathrm{S}$, Reisman A, Wilner KD, et al, and PROFILE 1014 Investigators. First-line crizotinib versus chemotherapy in ALK-positive lung cancer. N Engl J Med. 2014; 371:216777.

58. Choi YL, Soda M, Yamashita Y, Ueno T, Takashima J, Nakajima T, Yatabe Y, Takeuchi K, Hamada T, Haruta H, Ishikawa Y, Kimura H, Mitsudomi T, et al, and ALK Lung Cancer Study Group. EML4-ALK mutations in lung cancer that confer resistance to ALK inhibitors. N Engl J Med. 2010; 363:1734-39.

59. Zhang S, Anjum R, Squillace R, Nadworny S, Zhou T, Keats J, Ning Y, Wardwell SD, Miller D, Song Y, Eichinger L, Moran L, Huang WS, et al. The Potent ALK Inhibitor Brigatinib (AP26113) Overcomes Mechanisms of Resistance to First- and Second-Generation ALK Inhibitors in Preclinical Models. Clin Cancer Res. 2016; 22:5527-38.

60. Ceritinib gains FDA approval for lung cancer. Cancer Discov. 2014; 4:753-54.

61. Kim DW, Mehra R, Tan DS, Felip E, Chow LQ, Camidge DR, Vansteenkiste J, Sharma S, De Pas T, Riely GJ, Solomon BJ, Wolf J, Thomas M, et al. Activity and safety of ceritinib in patients with ALK-rearranged non-smallcell lung cancer (ASCEND-1): updated results from the multicentre, open-label, phase 1 trial. Lancet Oncol. 2016; 17:452-63.

62. Landi L, Cappuzzo F. Ceritinib for the treatment of patients with anaplastic lymphoma kinase (ALK)-positive metastatic non-small cell lung cancer. Expert Rev Clin Pharmacol. 2016; 9:203-14.

63. Gadgeel SM, Gandhi L, Riely GJ, Chiappori AA, West HL, Azada MC, Morcos PN, Lee RM, Garcia L, Yu L, Boisserie F, Di Laurenzio L, Golding S, et al. Safety and activity of alectinib against systemic disease and brain metastases in patients with crizotinib-resistant ALK-rearranged non- small-cell lung cancer (AF-002JG): results from the dosefinding portion of a phase 1/2 study. Lancet Oncol. 2014; 15:1119-28.

64. Shaw AT, Gandhi L, Gadgeel S, Riely GJ, Cetnar J, West H, Camidge DR, Socinski MA, Chiappori A, Mekhail T, Chao $\mathrm{BH}$, Borghaei $\mathrm{H}$, Gold KA, et al, and study investigators. Alectinib in ALK-positive, crizotinib-resistant, non-smallcell lung cancer: a single-group, multicentre, phase 2 trial. Lancet Oncol. 2016; 17:234-42.

65. Santarpia M, Altavilla G, Rosell R. Alectinib: a selective, next-generation ALK inhibitor for treatment of ALKrearranged non-small-cell lung cancer. Expert Rev Respir Med. 2015; 9:255-68.

66. Kim DW, Tiseo M, Ahn MJ, Reckamp KL, Hansen KH, Kim SW, Huber RM, West HL, Groen HJ, Hochmair MJ, Leighl NB, Gettinger SN, Langer CJ, et al. Brigatinib in Patients With Crizotinib-Refractory Anaplastic Lymphoma Kinase-Positive Non-Small-Cell Lung Cancer: A Randomized, Multicenter Phase II Trial. J Clin Oncol. 2017; 35:2490-98.

67. Das M. Brigatinib effective in ALK-positive non-small-cell lung cancer. Lancet Oncol. 2017; 18:e310.

68. Uchibori K, Inase N, Araki M, Kamada M, Sato S, Okuno Y, Fujita N, Katayama R. Brigatinib combined with antiEGFR antibody overcomes osimertinib resistance in EGFRmutated non-small-cell lung cancer. Nat Commun. 2017; $8: 14768$.

69. Farago AF, Le LP, Zheng Z, Muzikansky A, Drilon A, Patel M, Bauer TM, Liu SV, Ou SH, Jackman D, Costa DB, Multani PS, Li GG, et al. Durable Clinical Response to Entrectinib in NTRK1-Rearranged Non-Small Cell Lung Cancer. J Thorac Oncol. 2015; 10:1670-74.

70. Hochmair MJ, Schwab S, Prosch H. Complete remission of intrathecal metastases with lorlatinib therapy in a heavily pretreated ALK-positive lung cancer patient. Anticancer Drugs. 2017; 28:928-30.

71. Lorlatinib Is Active in Drug-Resistant NSCLC. Cancer Discov. 2016; 6:F1.

72. Dugay F, Llamas-Gutierrez F, Gournay M, Medane S, Mazet F, Chiforeanu DC, Becker E, Lamy R, Léna H, Rioux-Leclercq N, Belaud-Rotureau MA, Cabillic F. Clinicopathological characteristics of ROS1- and RETrearranged NSCLC in caucasian patients: data from a cohort of 713 non-squamous NSCLC lacking KRAS/EGFR/ HER2/BRAF/PIK3CA/ALK alterations. Oncotarget. 2017; 8:53336-51. https://doi.org/10.18632/oncotarget.18408

73. Lim SM, Kim HR, Lee JS, Lee KH, Lee YG, Min YJ, Cho EK, Lee SS, Kim BS, Choi MY, Shim HS, Chung JH, La Choi Y, et al. Open-Label, Multicenter, Phase II Study of Ceritinib in Patients With Non-Small-Cell Lung Cancer Harboring ROS1 Rearrangement. J Clin Oncol. 2017; 35:2613-18.

74. Uguen A, Schick U, Quéré G. A Rare Case of ROS1 and ALK Double Rearranged Non-Small Cell Lung Cancer. J Thorac Oncol. 2017; 12:e71-72. 
75. Roskoski R Jr. ROS1 protein-tyrosine kinase inhibitors in the treatment of ROS1 fusion protein-driven non-small cell lung cancers. Pharmacol Res. 2017; 121:202-12.

76. Goldman JM, Gray JE. BRAF V600E mutations: a series of case reports in patients with non-small cell lung cancer. Cancer Genet. 2015; 208:351-54.

77. Kinno T, Tsuta K, Shiraishi K, Mizukami T, Suzuki M, Yoshida A, Suzuki K, Asamura H, Furuta K, Kohno T, Kushima R. Clinicopathological features of nonsmall cell lung carcinomas with BRAF mutations. Ann Oncol. 2014; 25:138-42.

78. Brustugun OT, Khattak AM, Trømborg AK, Beigi M, Beiske K, Lund-Iversen M, Helland $\AA$. BRAF-mutations in non-small cell lung cancer. Lung Cancer. 2014; 84:36-38.

79. Gorka E, Fabó D, Gézsi A, Czirbesz K, Fedorcsák I, Liszkay G. Dabrafenib Therapy in 30 Patients with Melanoma Metastatic to the Brain: a Single-centre Controlled Retrospective Study in Hungary. Pathol Oncol Res. 2017 Jun 1. https://doi.org.10.1007/s12253-017-02569. [Epub ahead of print].

80. Robinson SD, O'Shaughnessy JA, Cowey CL, Konduri K. BRAF V600E-mutated lung adenocarcinoma with metastases to the brain responding to treatment with vemurafenib. Lung Cancer. 2014; 85:326-30.

81. Wang J, Chen J, Guo Y, Wang B, Chu H. Strategies targeting angiogenesis in advanced non-small cell lung cancer. Oncotarget. 2017; 8:53854-72. https://doi.org/10.18632/ oncotarget. 17957.

82. Aggarwal C, Somaiah N, Simon G. Antiangiogenic agents in the management of non-small cell lung cancer: where do we stand now and where are we headed? Cancer Biol Ther. 2012; 13:247-63.

83. Brooks AN, Kilgour E, Smith PD. Molecular pathways: fibroblast growth factor signaling: a new therapeutic opportunity in cancer. Clin Cancer Res. 2012; 18:1855-62.

84. Lohela M, Bry M, Tammela T, Alitalo K. VEGFs and receptors involved in angiogenesis versus lymphangiogenesis. Curr Opin Cell Biol. 2009; 21:154-65.

85. Abramsson A, Lindblom P, Betsholtz C. Endothelial and nonendothelial sources of PDGF-B regulate pericyte recruitment and influence vascular pattern formation in tumors. J Clin Invest. 2003; 112:1142-51.

86. Li F, Chen G, Jiao S. Bevacizumab Combined with Chemotherapy as First-line Therapy for Advanced Non-Small Cell Lung Cancer: A Retrospective Study. Hepatogastroenterology. 2015; 62:797-801.

87. Barlesi F, Scherpereel A, Gorbunova V, Gervais R, Vikström A, Chouaid C, Chella A, Kim JH, Ahn MJ, Reck M, Pazzola A, Kim HT, Aerts JG, et al. Maintenance bevacizumabpemetrexed after first-line cisplatin-pemetrexedbevacizumab for advanced nonsquamous nonsmall-cell lung cancer: updated survival analysis of the AVAPERL (MO22089) randomized phase III trial. Ann Oncol. 2014; 25:1044-52.
88. Barlesi F, Scherpereel A, Rittmeyer A, Pazzola A, Ferrer Tur N, Kim JH, Ahn MJ, Aerts JG, Gorbunova V, Vikström A, Wong EK, Perez-Moreno P, Mitchell L, Groen HJ. Randomized phase III trial of maintenance bevacizumab with or without pemetrexed after first-line induction with bevacizumab, cisplatin, and pemetrexed in advanced nonsquamous non-small-cell lung cancer: AVAPERL (MO22089). J Clin Oncol. 2013; 31:3004-11.

89. Nadler E, Yu E, Ravelo A, Sing A, Forsyth M, Gruschkus S. Bevacizumab treatment to progression after chemotherapy: outcomes from a U.S. community practice network. Oncologist. 2011; 16:486-96.

90. Reck M, von Pawel J, Zatloukal P, Ramlau R, Gorbounova V, Hirsh V, Leighl N, Mezger J, Archer V, Moore N, Manegold C. Phase III trial of cisplatin plus gemcitabine with either placebo or bevacizumab as first-line therapy for nonsquamous non-small-cell lung cancer: AVAil. J Clin Oncol. 2009; 27:1227-34.

91. Ocvirk J, Moltara ME, Mesti T, Boc M, Rebersek M, Volk N, Benedik J, Hlebanja Z. Bevacizumab plus chemotherapy in elderly patients with previously untreated metastatic colorectal cancer: single center experience. Radiol Oncol. 2016; 50:226-31.

92. Yoh K, Hosomi Y, Kasahara K, Yamada K, Takahashi T, Yamamoto N, Nishio M, Ohe Y, Koue T, Nakamura T, Enatsu S, Lee P, Ferry D, et al. A randomized, double-blind, phase II study of ramucirumab plus docetaxel vs placebo plus docetaxel in Japanese patients with stage IV non-small cell lung cancer after disease progression on platinum-based therapy. Lung Cancer. 2016; 99:186-93.

93. Tabernero J, Yoshino T, Cohn AL, Obermannova R, Bodoky G, Garcia-Carbonero R, Ciuleanu TE, Portnoy DC, Van Cutsem E, Grothey A, Prausová J, Garcia-Alfonso P, Yamazaki K, et al, and RAISE Study Investigators. Ramucirumab versus placebo in combination with secondline FOLFIRI in patients with metastatic colorectal carcinoma that progressed during or after first-line therapy with bevacizumab, oxaliplatin, and a fluoropyrimidine (RAISE): a randomised, double-blind, multicentre, phase 3 study. Lancet Oncol. 2015; 16:499-508.

94. Wilke H, Muro K, Van Cutsem E, Oh SC, Bodoky G, Shimada Y, Hironaka S, Sugimoto N, Lipatov O, Kim TY, Cunningham D, Rougier P, Komatsu Y, et al, and RAINBOW Study Group. Ramucirumab plus paclitaxel versus placebo plus paclitaxel in patients with previously treated advanced gastric or gastro-oesophageal junction adenocarcinoma (RAINBOW): a double-blind, randomised phase 3 trial. Lancet Oncol. 2014; 15:1224-35.

95. Tan AC, Heimberger AB, Menzies AM, Pavlakis N, Khasraw M. Immune Checkpoint Inhibitors for Brain Metastases. Curr Oncol Rep. 2017; 19:38.

96. Berghoff AS, Venur VA, Preusser M, Ahluwalia MS. Immune Checkpoint Inhibitors in Brain Metastases: From Biology to Treatment. Am Soc Clin Oncol Educ Book. 2016; 35:e116-22. 
97. Brahmer J, Reckamp KL, Baas P, Crinò L, Eberhardt WE, Poddubskaya E, Antonia S, Pluzanski A, Vokes EE, Holgado E, Waterhouse D, Ready N, Gainor J, et al. Nivolumab versus Docetaxel in Advanced SquamousCell Non-Small-Cell Lung Cancer. N Engl J Med. 2015; 373:123-35.

98. Garon EB, Rizvi NA, Hui R, Leighl N, Balmanoukian AS, Eder JP, Patnaik A, Aggarwal C, Gubens M, Horn L, Carcereny E, Ahn MJ, Felip E, et al, and KEYNOTE-001 Investigators. Pembrolizumab for the treatment of nonsmall-cell lung cancer. N Engl J Med. 2015; 372:2018-28.
99. Weinstock C, Khozin S, Suzman D, Zhang L, Tang S, Wahby S, Goldberg KB, Kim G, Pazdur R. U.S. Food and Drug Administration Approval Summary: Atezolizumab for Metastatic Non-Small Cell Lung Cancer. Clin Cancer Res. 2017; 23:4534-39.

100. Chan PY, Hall P, Hay G, Cohen VM, Szlosarek PW. A major responder to ipilimumab and nivolumab in metastatic uveal melanoma with concomitant autoimmunity. Pigment Cell Melanoma Res. 2017; 30:558-62.

101. Cooper JS. Radiation Therapy Followed by Ipilimumab Is Appropriate. Int J Radiat Oncol Biol Phys. 2017; 98:13. 